\title{
Emerging Treatment Regimens in Psoriasis: Are There Advantages Over Current Biologic Therapies?
}

\author{
Authors: \\ *Joeseph M. Nenow, ${ }^{1}$ Esther A. Balogh, ${ }^{2}$ Steven R. Feldman ${ }^{1,2,3,4}$ \\ 1. Center for Dermatology Research, Department of Dermatology, Wake Forest \\ School of Medicine, Winston-Salem, North Carolina, USA \\ 2. Department of Pathology, Wake Forest School of Medicine, Winston-Salem, North \\ Carolina, USA \\ 3. Department of Social Sciences \& Health Policy, Wake Forest School of Medicine, \\ Winston Salem, North Carolina, USA \\ 4. Department of Dermatology, University of Southern Denmark, Odense, Denmark \\ *Correspondence to josephnenow@gmail.com \\ Disclosure: $\quad$ Feldman has received research, speaking, and/or consulting support from \\ Galderma, GlaxoSmithKline (GSK)/Stiefel, Almirall, Leo Pharma, Boehringer \\ Ingelheim, Mylan, Celgene, Pfizer, Valeant, Abbvie, Samsung, Janssen, Lilly, Menlo, \\ Merck, Novartis, Regeneron, Sanofi, Novan, Qurient, National Biological Corporation, \\ Caremark, Advance Medical, Sun Pharma, Suncare Research, Informa, UpToDate, \\ and National Psoriasis Foundation; is founder and majority owner of www.DrScore. \\ com; and founder and part owner of Causa Research, a company dedicated to \\ enhancing patients' adherence to treatment. The other authors have declared no \\ conflicts of interest.
}

Received: $\quad 14.07 .21$

Accepted: $\quad 08.10 .21$

Keywords: $\quad$ Adherence, antagonist, IL-17, IL-23, JAK inhibitors, naltexone, plaque psoriasis, psoriatic arthritis, retinoic acid receptor-related orphan receptor $\mathrm{y}$ antagonist.

Citation:

EMJ Dermatol. 2021;9[1]:106-121.

\section{Abstract}

Psoriasis is a chronic inflammatory skin condition that impacts patients' quality of life and has large economic consequences. While current biologics are remarkable for their efficacy and safety, opportunities for improvement exist due to their rare side effects, fading efficacy, method of delivery, and expense. Biologics such as bimekizumab offer high likelihood of clearance, while oral options (e.g., deucravacitinib) allow patients to avoid injections and achieve efficacies similar to adalimumab or ustekinumab. As a result, there is limited room for the development of new biologics. Several oral therapies such as the oral monoclonal microbial EDP1815 have the potential to meet patient expectations for efficacy and convenient administration. However, emerging treatment regimens for plaque psoriasis will increasingly require a multimodal approach, addressing patient adherence, lifestyle choices, and awareness of the individual's underlying pathophysiological processes. In this narrative review, the authors discuss recent advances in the development of biologic and oral small molecules for plaque psoriasis. 


\section{BACKGROUND: PSORIASIS STANDARD OF CARE}

\section{Disease Background and Overview of Treatment}

Psoriasis is a chronic inflammatory skin condition that affects $2-3 \%$ of the population in the USA and has extensive psychosocial and economic consequences. ' Sustained inflammation leads to uncontrolled proliferation and differentiation of keratinocytes. Although psoriasis variants share a root pathophysiology, variations in pathways lead to variable treatment effectiveness. ${ }^{2}$ There are three categories of treatment for plaque psoriasis: topical medications, phototherapy, and systemic therapies. Topical therapies are the first-line treatment for localised psoriasis.3., Ultraviolet (UV) light can be used for localised and extensive psoriasis. ${ }^{3}$ Home phototherapy units can reduce cost and increase convenience. Nevertheless, the use of UV for moderateto-severe psoriasis is declining in popularity, likely due to perceived high price, poor reimbursement, and the availability of highly effective, safe, and more convenient systemic treatments. ${ }^{5-7}$ The presence of moderate-tosevere disease often requires treatment with systemic therapies. Of the available systemic treatments, current professional dermatological association guidelines recommend biologics for the treatment of moderate-to-severe plaque psoriasis that is recalcitrant to local therapies. ${ }^{8}$

\section{Systemic Therapy: Indications and General Options}

Among biologic therapies, three classes are used for moderate-to-severe psoriasis: TNF-a inhibitors, IL-17 inhibitors, and IL-23 inhibitors. ${ }^{8}$

\section{TNF-a inhibitors}

The first generation of TNF-a inhibitors has potent initial efficacies. The most common method of reporting efficacy is the Psoriasis Area and Severity Index (PASI), a standard tool for scoring psoriasis severity. Following 12 weeks of use for infliximab or adalimumab, PASI90 (i.e., a 90\% improvement from baseline) was achieved in approximately $50 \%$ of patients in treatment arms. ${ }^{9-11}$ PASI75 was achieved by $49 \%$ of patients treated with etanercept $50 \mathrm{mg}$ twice a week at 12 weeks $(p<0.0001)$. When combined with phototherapy, etanercept therapies have achieved a PASI9O in 58.1\% over the same timeframe. ${ }^{12,13}$ These strong initial responses often fade. In the Danish DERMBIO registry study of 1,867 psoriasis treatment courses, $41.3 \%$ of these regimens were discontinued. The most common reason for discontinuation was the loss of efficacy (67.0\%). ${ }^{14}$ TNF-a inhibitors are contraindicated in those with a strong family history of malignancy or chronic infection (e.g., tuberculosis, hepatitis B virus). ${ }^{3}$ As a result, there was an opportunity to develop novel therapies that averted some of the major class side effects, including the risk of serious infections (e.g., tuberculosis), malignancy, and major adverse cardiovascular events. ${ }^{15}$

TNF-a inhibitors also face competition from biosimilars. Recent adalimumab biosimilars include mjevita (adalimumab-atto), Cyltezo (adalimumab-adbm), Hyrimoz (adalimumabadaz), Hadlima (adalimumab-bwwd), Abrilada (adalimumab-afzb), and Hulio (adalimumabfkjp), with more on the way. Infliximab biosimilars include Inflectra (infliximab-dyyb), Renflexis (infliximab-abda), Ixifi (infliximab$q b t x$ ), and Avsola (infliximab-axxq). ${ }^{16-19}$ The influx of competitive agents may lead to a decrease in cost.

\section{IL-17/23 axis}

The IL-17/IL-23 axis is central to psoriasis pathophysiology, and inhibitors of these cytokines are effective psoriasis treatments. ${ }^{3}$ The IL-17 inhibitor class consists of secukinumab, ixekizumab, and brodalumab.4,8 The IL-23 inhibitor class contains inhibitors to the p19 subunit of IL-23 (guselkumab, tildrakizumab, and risankizumab) and ustekinumab, which binds the p40 subunit of IL-23 that is also in IL-12. ${ }^{4}$ Many of these agents are both highly efficacious and generally well tolerated when used as treatments for moderate-to-severe plaque psoriasis. Ustekinumab, secukinumab, ixekizumab, brodalumab, guselkumab, and tildrakizumab have all entered clinical use for the treatment of moderate-to-severe plaque psoriasis. ${ }^{20}$ In a systematic review, ixekizumab appears to be the most effective short-term agent (i.e., greatest PASI75/90 over 12 weeks [ $p<0.00001 / 0.00001]$ ). It is also the most likely to be associated with one or more adverse effects (AE) $(p<0.00001)$. Ixekizumab $80 \mathrm{mg}$, risankizumab $150 \mathrm{mg}$, and 
brodalumab $210 \mathrm{mg}$ have similar numbers needed to treat for PASI75 (1.18, 1.19, and 1.19, respectively). ${ }^{21}$

As novel therapies, the long-term AEs of the IL-17 and IL-23 classes are not fully known. Throughout recent years of clinical testing, they appear to be very safe. However, similarly to TNF-a inhibitors, efficacy can fade over time, perhaps due to neutralising antibodies.,22 Unfortunately, these therapies can cost 50,000 USD or more annually. ${ }^{23}$ Though with several exceptions, most require administration by injection, which can be unfavourable for some patients. 3,24

\section{EMERGING THERAPIES}

\section{Biologics}

\section{IL-17 inhibitor: bimekizumab}

Bimekizumab is an injectable lgG1 monoclonal antibody targeting IL-17A and IL-17F under development by UCB (Brussels, Belgium). Bimekizumab recently completed a direct comparison study against secukinumab in the BE RADIANT study, following its completion of comparison studies against adalimumab (BE SURE) and ustekinumab (BE VIVID). In this randomised, multicentre, double-blind study bimekizumab was compared to secukinumab, with the primary endpoint of PASI10O at 16 weeks. ${ }^{25}$ At 16 weeks, $61.7 \%$ of the bimekizumab arm achieved PASIIOO versus $48.9 \%$ in the secukinumab arm. Analysis proved bimekizumab to be non-inferior, and, subsequently, superior to secukinumab ( $p<0.001$ each). After 48 weeks, $67.0 \%$ of the bimekizumab arm achieved PASI100 compared with $46.2 \%$ in the secukinumab arm. However, it must be noted that there was a documented greater association with oral candidiasis in the bimekizumab arm. ${ }^{26}$

In the BE SURE trial, the most common side effects for bimekizumab were found to be nasopharyngitis (20.9\%), oral candida infection (16.2\%), and upper respiratory tract infection (9.0\%). Throughout the trial, no serious AEs were reported in the treatment arm. Potential serious AEs included suicidal ideation or behaviour, inflammatory bowel disease, or major adverse cardiac events.

Previously, bimekizumab had undergone a Phase
III, randomised, double blind, placebo-controlled trial (BE READY) ${ }^{27}$ The study enrolled 435 adults with moderate-to-severe plaque psoriasis. It consisted of an initial treatment period followed by a randomised withdrawal period lasting a combined 56 weeks. BE READY met its primary endpoints of PASI9O and an Investigator's Global Assessment (IGA) response of clear or almost clear (IGA O/1) compared to placebo after 16 weeks of treatment. ${ }^{27}$

In a previous Phase Ilb study (BE ABLE 1) on bimekizumab's safety, there was no association of bimekizumab with any dose-related safety risks or unexpected safety signals in a set of 250 patients. Treatment-emergent AEs occurred in $61 \%(126 / 208)$ of bimekizumab patients compared with $36 \%$ (15/42) of patients in the placebo arm. These AEs led to a study discontinuation rate of $4.8 \%(10 / 208)$ in the bimekizumab arm and $2.4 \%(1 / 42)$ in the placebo arm. The side effects leading to discontinuation included the diagnosis of colon cancer and, in a separate case, a large gastrointestinal polyp, which was deemed unrelated to the study treatment by the investigator. ${ }^{28}$

\section{Inhibitory receptor agonist: CC-90006}

CC-90006 is a subcutaneous injection programmed cell death protein-1 agonist antibody being developed by Celgene (Uxbridge, UK) for the treatment of mild-to-moderate plaque-type psoriasis. It recently completed Phase I testing in a multicentre, randomised, double-blind, placebo-controlled, multipledose study to evaluate drug safety, tolerability, pharmacokinetics, and pharmacodynamics in 34 participants with mild-to-moderate plaque-type psoriasis. ${ }^{29}$ No results are currently available for this or any other previous trials. Phase I testing was completed on April 26 2019 , but results have not yet been posted. ${ }^{29,30}$

\section{Oral Small Molecules}

\section{JAK family}

\section{Filgotinib (GLPG0634)}

Filgotinib (GLPG0634) is an oral, selective JAK1 inhibitor developed by Galapagos (Mechelen, Belgium) for use in adults with psoriatic arthritis (PsA), ulcerative colitis, and Crohn's disease. Filgotinib was recently approved 
for the treatment of rheumatoid arthritis by the European Medicines Agency (EMA) and Pharmaceuticals and Medical Devices Agency (PMDA), with initial clinical use beginning in 2020. In the USA, under a collaborative agreement, Gilead (Foster City, California) sought U.S. Food and Drug Administration (FDA) approval of filgotinib for rheumatoid arthritis. In August 2020, they discontinued the pursuit for approval in the USA. ${ }^{31}$ Results from the previous Phase II EQUATOR trial,32 a randomised, placebocontrolled trial for moderate-to-severely active PsA, are available. Primary study endpoints were based on American College of Rheumatologists 20 (ACR2O), a composite measure defined as the improvement in at least $20 \%$ of tender and swollen joints among additional criteria and while in a state of minimal disease activity. At 16 weeks, $80 \%(52 / 65)$ of patients in the filgotinib group achieved ACR2O compared to 33\% (22/66) in the placebo group $(p<0.0001){ }^{33}$ During the openlabel extension portion of the study, which was extended until 52 weeks, $33.6 \%$ of patients in the filgotinib arm achieved minimal disease activity response and 55.0\% achieved ACR50. ${ }^{34}$ The drug is currently advancing to the pivotal Phase III PENGUIN clinical trial programme to confirm the safety and efficacy. ${ }^{35}$

\section{PF-06826647}

PF-06826647 is an oral once daily tablet that acts through the inhibition of tyrosine kinase 2 . It is being developed by Pfizer (New York City, New York, USA) for patients with moderate-tosevere plaque psoriasis. The drug is currently in a randomised, double-masked, parallel assignment, Phase II study of 179 participants to investigate its safety and efficacy for patients with moderateto-severe plaque psoriasis. ${ }^{36}$ The study was nominally completed on $26^{\text {th }}$ November 2020, with results currently undergoing quality control as of $3^{\text {rd }}$ May $2021 .^{36}$

In a previous Phase I trial of PF-06826647 investigating safety, there were no clinically relevant differences in physical exam or lab data between the $400 \mathrm{mg}, 100 \mathrm{mg}$, and placebo arms. $^{37}$ In the psoriasis cohort, the patients in the $400 \mathrm{mg}$ treatment arm experienced AEs at a rate of $80.0 \%$ compared to $45.5 \%$ in the 100 $\mathrm{mg}$ arm and $50 \%$ in the placebo arm. All AEs were mild in severity, but were not individually identifed. No serious or severe AEs of clinical relevance were reported. ${ }^{37}$

\section{BMS-986165 (deucravacitinib)}

BMS-986165 (deucravacitinib) is an oral selective tyrosine kinase 2 inhibitor developed by Bristol Myers Squibb (Uxbridge, UK) for the treatment of patients with moderate-tosevere plaque psoriasis. In recently published data from the POETYK PSO-138 and PSO-2 ${ }^{39}$ Phase II trials, $58.7 \% / 53.6 \%$ of patients receiving deucravacitinib achieved PASI75 as compared to $35.1 \% / 40.2 \%$ receiving apremilast, and $12.7 / 9.4 \%$ in placebo groups at 16 weeks. Following 24 weeks of treatment, $69.0 \% / 59.3 \%$ of patients reached PASI75 compared to $38.1 \% / 37.8 \%$ receiving apremilast. Of the patients achieving PASI75 at 24 weeks, $82.5 \% / 81.4 \%$ of patients in the PSO-1/PSO-2 trials maintained PASI75 response at 52 weeks. No serious or severe AEs were reported, including severe or opportunistic infections or thrombotic events. Among mild AEs, nasopharyngitis (5.7-17.9\% versus $7.6 \%$ placebo) and sinusitis ( $0-7.6 \%$ versus $0 \%$ placebo) were the most reported complaints. ${ }^{37,40}$

\section{Receptor antagonists}

\section{Nuclear receptor antagonist: BI 730357}

$\mathrm{BI} 730357$ is a film-coated tablet that acts as a pyrazinone retinoic acid receptor orphan receptor $\mathrm{Y}$ (RORY) antagonist. It is a ligandregulated transcriptional factor with diverse roles in cell proliferation and differentiation. ${ }^{41}$ It is being developed by Boehringer Ingelheim (Ingelheim am Rhein, Germany) for the treatment of moderate-to-severe plaque psoriasis. It is currently in a Phase II, interventional, randomised, double-blind, placebo-controlled long-term extension study of 180 participants to assess safety, tolerability, and efficacy in patients with moderate-to-severe plaque psoriasis. ${ }^{42}$ It is estimated to be completed on $28^{\text {th }}$ February 2027.42 A previous, shorter-term Phase II study on safety, tolerability, and efficacy in 274 patients with moderate-to-severe plaque psoriasis was completed in June 2021, but no results are currently available. ${ }^{43}$

\section{IL-2 receptor agonist: C-92252}

CC-92252 is an IL-2 receptor agonist and regulatory T-lymphocyte stimulant currently being developed by the Celgene for the 
treatment of adults with psoriasis. It is now in Phase I of clinical development in a threepart interventional, randomised, parallel assignment study with quadruple masking. ${ }^{44}$ With 133 enrolled participants, the study aims to evaluate pharmaceutical safety, tolerability, pharmacokinetics, and pharmacodynamics of ascending doses of CC-92252 in both healthy adult subjects and adult subjects with psoriasis. It is estimated to be completed on $30^{\text {th }}$ September $2022 .{ }^{44}$

\section{Anti-inflammatory agents}

\section{$\mu$-opioid antagonists (naltrexone)}

Naltrexone is a $\mu$-opioid antagonist taken orally and is under study for treatment of mild psoriasis by the Jinnah Postgraduate Medical Centre (JPMC; Karachi, Pakistan). The therapy has recently completed a Phase I clinical trial for the use of low-dose naltrexone in mild psoriasis in a tertiary care hospital in Karachi, Pakistan. ${ }^{45}$ This interventional, single group assignment trial with no masking of 42 participants was completed on $30^{\text {th }}$ September 2019. Following 12 weeks of low-dose naltrexone, relevant markers of psoriasis severity decreased compared with patient baseline before treatment: PASI by 4.96 $(p<0.001)$, Dermatology Life Quality Index (DLQI) by $6.32(p<0.001)$, and Investigator's Global Assessment and Body Surface Area (IGA*BSA) by $3.9(p<0.001)$. The efficacy of the drug may be due to regulation of lymphocyte responses, reduced cytokine production, and decreased mast cell activity. Via reduction of pruritus, systemic naltrexone can act in an adjunctive role to control patient scratching behaviours and minimise physical trauma to the affected area. Low-dose naltrexone is generally considered safe, but mood and liver abnormalities have occasionally been reported at high doses. ${ }^{46,47}$

\section{Cannabinoids}

The endocannabinoid system maintains many aspects of skin homeostasis, such as proliferation, differentiation, and release of inflammatory mediators. ${ }^{48}$ Cannabinoids may aid in the management of cutaneous diseases. They can act directly via neuronal modulation of peripheral itch fibres. They can also act centrally on cannabinoid receptors with additional unspecified actions in the endocannabinoid system and cholinergic anti-inflammatory pathway. ${ }^{48,49}$ In refractory cases following standard therapies, cannabinoid formulations may be considered as an adjuvant therapy due to their ability to reduce symptoms of chronic pruritus in limited human studies. ${ }^{48,50}$

Brown University (Providence, Rhode Island, USA) has begun to investigate the impact of cannabis on pain and inflammation in patients with arthritis. In a Phase II, randomised, placebo-controlled, cross-over assignment, double-blind study. ${ }^{49}$ Brown University is exploring the effects of oral medium tetrahydrocannabinol or cannabidiol on pain symptomology and inflammatory markers in patients with rheumatoid or PsA. The study consists of 76 participants and has an estimated completion date of $31^{\text {st }}$ July $2022 .{ }^{49}$

\section{Oral microbials}

\section{EDP1815}

EDP1815 is an oral tablet form of a monoclonal strain of Prevotella histicola, selected for its potent anti-inflammatory pharmacology. It is being developed by Evelo Biosciences (Cambridge, Massachusetts, USA). It is currently in Phase II of development for the treatment of mild-to-moderate plaque psoriasis. ${ }^{51}$

In a Phase II, multicentre, randomised, doubleblind, placebo-controlled trial, EDP1815 is being investigated for its efficacy and safety in the treatment of 225 participants with mild-tomoderate plaque psoriasis. It aims to identify an optimal dose in these patients and is expected to be completed by $23^{\text {rd }}$ December $2021 .^{52}$

Previously, EDP1815 had been explored in a Phase I, randomised, double-blind, placebocontrolled, ascending dose study in healthy participants, patients with atopic dermatitis and patients with mild-to-moderate psoriasis. ${ }^{53}$ The study was completed on $31^{\text {st }}$ October 2019. Results are compared to placebo and following a 56-day treatment regimen. In the atopic dermatitis cohorts, there was a $62 \%$ difference in Eczema Area and Severity Index (EASI) score $(p=0.034)$ and $71 \%$ difference $(p=0.019)$ in IGA*BSA. On Day 56, 10/16 patients showed improvements in EASI, with three of those ten patients achieving an EASI75 clinical response. In the psoriasis cohorts, EDP1815 limited the production of inflammatory-mediator cytokines, including IL-1, -6 , and -8 , and TNF. There was no 
statistical significance in the incidence of nausea, vomiting, diarrhoea, or abdominal pain between treatment and placebo arms. No serious side effects were reported. ${ }^{54}$

\section{PSORIASIS PHARMACOLOGY IN BROADER CONTEXT}

Compared to today's standard of care (e.g., IL17/IL-23 inhibitors) (Table 1), emerging agents (Table 2) do not show apparent advantages in terms of efficacy or safety. Emerging agents will likely need to demonstrate a benefit outside of clinical efficacy (e.g., cost or ease of use) to ensure clinical adoption. By comparison, the pharmacology of the future promises increased effectiveness and adherence through personalisation. Technological advances in tissue imaging, analysis, and proteogenomics will elucidate disease pathophysiology and help individualise treatment regimens. ${ }^{67,68}$ Recent discoveries in inflammatory marker and regulator systems (including pentraxin, receptor-acting protein kinases, and mixedlineage kinase domain-like pseudokinase) offer potential targets for therapeutic intervention. ${ }^{69,70}$ As advances are made in the understanding of mRNA regulation in psoriasis, opportunities will arise for more accurate monitoring and efficacious intervention. ${ }^{69,71,72}$

Exclusive discussion of pharmacology creates an incomplete picture of the advances made in psoriasis management. Understanding and combating poor medication adherence is essential to improving clinical outcomes. Currently, poor adherence not only leads to poor clinical outcomes, but also skews clinical trial data. It is important to note that adherence in clinical trials may be higher than in daily life when dosing is not monitored. ${ }^{73}$

Persistence rates vary significantly by agent and class. In a 2015 cross-sectional study, persistence rates were 19\% for etanercept, 53\% for adalimumab, and $71 \%$ for ustekinumab over 12 months $(p<0.05) .^{74}$ In a study of ustekinumab, which measured patient persistence rates over 6 months, ustekinumab showed a persistence rate of $81.4 \%$; this is similar to the $80.6 \%$ and 87.4\% persistence rates as seen in ixekizumab patients. ${ }^{75}$ The underlying reasons for these varying persistence rates remain complex.
In one study, the most reported reason for discontinuing a psoriasis treatment regimen was 'ineffective treatment' (cited by $64.7 \%$ of patients). Poor dose-escalation schedule may impact these findings as patients may be pre-emptively discontinuing treatment due to perceived lack of efficacy. Alternatively, class efficacy may play a role. After switching to an IL17 inhibitor, $45.7 \%$ of patients reported symptoms as "better," while $26.5 \%$ reported no change in symptoms. Patients are more adherent to treatment regimens if their prescribing provider had specialty training in rheumatology. ${ }^{76}$ This finding may be due to greater adherence from patients with joint symptomology or the association of joint symptomatology with more severe skin findings. When appropriately treated, this patient population may experience greater improvement in quality of life than patients without rheumatological findings.

Medication adherence is associated with numerous factors outside of the treatment class used. Important negative predictors of adherence include a negative emotional state (i.e., presence of anxiety or depression) and unaddressed concerns regarding the disease, medication side effects, or potential for medication overuse. The evidence between demographic traits and adherence is more mixed, and definitive conclusions cannot be drawn.77,78 For patients with poor medication adherence, the three most common reasons for missing doses included forgetting (49\%), feeling unwell (26\%), and being too busy (15\%). ${ }^{77}$ eHealth interventions (e.g., app notification services) have some effectiveness in using patient data to improve treatment adherence. ${ }^{73,79-81}$ Through clinical deployment, they may improve adherence through patient education and assistance in scheduling medication administration.

\section{CONCLUSION}

Overall, many patients with psoriasis have mild disease and could be adequately treated with a combination of topical treatments and phototherapy. For those requiring systemic treatment, current biologic therapies provide safety and efficacy but can be costly. The current market is competitive. Excellent efficacy rates are available through bimekizumab for those who seek the highest 
likelihood of clearance. Oral options are available (e.g., deucravacitinib) with efficacies similar to adalimumab or ustekinumab. Current clinical trials display no clear advantage in efficacy (Table 3). As a result, there is little room for the development of new biologics. Several oral therapies, including oral monoclonal microbials EDP1066, can meet patient expectations as favourable and effective treatments of plaque psoriasis. Emerging treatment regimens for plaque psoriasis will increasingly require a multimodal approach addressing patient adherence, lifestyle choices, and awareness of the individual's underlying pathophysiological processes.

Table 1: Efficacy and adverse effects of current systemic plaque psoriasis therapies.

\begin{tabular}{|c|c|c|c|}
\hline Class & Agents & Efficacy (at 12 weeks) & Adverse effects \\
\hline TNF-a inhibitors & $\begin{array}{l}\text { Etanercept, } \\
\text { infliximab, } \\
\text { adalimumab }\end{array}$ & $\begin{array}{l}\text { Infliximab/adalimumab: } \\
\text { - PASI90: approximately } \\
50.0 \%{ }^{8-10} \\
\text { Etanercept: } \\
\text { - PASI75: } 49.0 \%{ }^{11} \\
\text { Etanercept + phototherapy: } \\
\text { - PASI90: } 58.1 \%^{12}\end{array}$ & $\begin{array}{l}\text { - Risk of serious infection } \\
\text { (TB, HBV) or malignancy }{ }^{14} \\
\text { - Some evidence of } \\
\text { increased development of } \\
\text { non-melanomatous skin } \\
\text { cancers }^{55} \\
\text { - Mixed evidence concerning } \\
\text { risk of heart failure } \\
\text { - Black box warnings for } \\
\text { increased risk of developing } \\
\text { active tuberculosis, invasive } \\
\text { fungal infections, and } \\
\text { opportunistic bacterial and } \\
\text { viral infections }\end{array}$ \\
\hline IL-23 Inhibitors & $\begin{array}{l}\text { Guselkumab, tildrakizumab, } \\
\text { risankizumab }\end{array}$ & $\begin{array}{l}\text { Guselkumab:57 } \\
\text { - PASI75: 50.0-100.0\% } \\
\text { - PASI90: 70.0-73.3\% (16 } \\
\text { weeks) } \\
\text { Tildrakizumab:58 } \\
\text { - PASI75: 66.3-74.4\% (16 } \\
\text { weeks) } \\
\text { Risankizumab:59 } \\
\text { - PASI90: 74.8-75.3\% (16 } \\
\text { weeks) }\end{array}$ & $\begin{array}{l}\text { - No statistical difference } \\
\text { in occurrence of serious } \\
\text { adverse effects versus } \\
\text { placebo. }{ }^{60,61} \\
\text { - Minor side effects such } \\
\text { as upper respiratory } \\
\text { infections, nasopharyngitis, } \\
\text { and headaches were } \\
\text { experienced widely across } \\
\text { all agents, including } \\
\text { guselkumab (49\%), } \\
\text { tildrakizumab (data not } \\
\text { available), and risankizumab } \\
\text { (56\%) at the end of } 16 \\
\text { weeks }{ }^{61,62}\end{array}$ \\
\hline
\end{tabular}


Table 1 continued.

\begin{tabular}{|c|c|c|c|}
\hline Class & Agents & Efficacy (at 12 weeks) & Adverse effects \\
\hline IL-17 Inhibitors & $\begin{array}{l}\text { Secukinumab, ixekizumab, } \\
\text { brodalumab }^{59}\end{array}$ & $\begin{array}{l}\text { Secukinumab:63,64 } \\
\text { - PASI75: 71.6-81.6\% } \\
\text { Brodalumab:63,65 } \\
\text { - PASI75: 77.0-82.0\% } \\
\text { Ixekizumab:63 } \\
\text { - PASI75: 76.7-82.8\% }\end{array}$ & $\begin{array}{l}\text { Secukinumab: }{ }^{64} \\
\text { - Most commonly associated } \\
\text { with nasopharyngitis, } \\
\text { headache, and diarrhoea } \\
\text { Brodalumab: }{ }^{65} \\
\text { - Most commonly associated } \\
\text { with upper respiratory } \\
\text { infections, nasopharyngitis, } \\
\text { and injection-site erythema. } \\
\text { - There are two documented } \\
\text { cases of neutropenia that } \\
\text { resolved with cessation } \\
\text { Ixekizumab: } \\
\text { - Has been associated with } \\
\text { hypertriglyceridaemia, } \\
\text { peripheral oedema, } \\
\text { hypersensitivity, and } \\
\text { urticaria } \\
\text { - Most commonly associated } \\
\text { with injection site erythema } \\
\text { (15\%) } \\
\text { - Risk of serious side effects } \\
\text { in one meta-analysis was } \\
\text { not significantly different } \\
\text { than placebo }\end{array}$ \\
\hline
\end{tabular}

HBV: hepatitis B virus; PASI75: Psoriasis Area and Severity Index with 75\% improvement from baseline; PASI90:

Psoriasis Area and Severity Index with 90\% improvement from baseline; TB: tuberculosis.

Table 2: Summary of discussed biologic and oral compounds.

\begin{tabular}{|c|c|c|c|c|c|c|c|}
\hline Compound & Company & Indications & $\begin{array}{l}\text { Development } \\
\text { state }\end{array}$ & $\begin{array}{l}\text { Route of } \\
\text { administration }\end{array}$ & $\begin{array}{l}\text { Mechanism of } \\
\text { action }\end{array}$ & Efficacy & Adverse effects \\
\hline Bimekizumab & $\begin{array}{l}\text { UCB (Brussels, } \\
\text { Belgium) }\end{array}$ & $\begin{array}{l}\text { Moderate- } \\
\text { to-severe } \\
\text { psoriasis }\end{array}$ & Phase III & Injectable & $\begin{array}{l}\text { Inhibition of } \\
\text { IL-17A and } \\
\text { IL-17F }\end{array}$ & $\begin{array}{l}\text { PASI100 } \\
61.7 \% \text { (16 } \\
\text { weeks), } \\
67.0 \% \text { (48 } \\
\text { weeks) }\end{array}$ & $\begin{array}{l}\text { Nasopharyngitis } \\
\text { ( } 20.9 \%) \text {, } \\
\text { oral candida } \\
\text { infection (16.2\%) } \\
\text { and upper } \\
\text { respiratory tract } \\
\text { infection (9.0\%) } \\
\text { (BE SURE) }\end{array}$ \\
\hline CC-90006 & $\begin{array}{l}\text { Calgene } \\
\text { (Uxbridge, UK) }\end{array}$ & $\begin{array}{l}\text { Mild-to- } \\
\text { moderate } \\
\text { plaque } \\
\text { psoriasis }\end{array}$ & Phase I & Injectable & PD-1 agonist & $\begin{array}{l}\text { No data } \\
\text { available }\end{array}$ & $\begin{array}{l}\text { No data } \\
\text { available }\end{array}$ \\
\hline
\end{tabular}


Table 2 continued.

\begin{tabular}{|c|c|c|c|c|c|c|c|}
\hline Compound & Company & Indications & $\begin{array}{l}\text { Development } \\
\text { state }\end{array}$ & $\begin{array}{l}\text { Route of } \\
\text { administration }\end{array}$ & $\begin{array}{l}\text { Mechanism of } \\
\text { action }\end{array}$ & Efficacy & Adverse effects \\
\hline $\begin{array}{l}\text { Filgotinib } \\
\text { (GLPG0634) }\end{array}$ & $\begin{array}{l}\text { Galapagos } \\
\text { (Mechelen, } \\
\text { Belgium) }\end{array}$ & $\begin{array}{l}\text { Psoriatic } \\
\text { arthritis, } \\
\text { ulcerative } \\
\text { colitis, and } \\
\text { Crohn's } \\
\text { disease }\end{array}$ & Phase II & Oral & $\begin{array}{l}\text { Selective JAK1 } \\
\text { inhibitor }\end{array}$ & $\begin{array}{l}\text { ACR2O, } \\
80 \%(16 \\
\text { weeks) } \\
\text { ACR50, } \\
55.0 \% \text { (52 } \\
\text { weeks) }{ }^{40}\end{array}$ & $\begin{array}{l}\text { Most commonly } \\
\text { associated with } \\
\text { nasopharyngitis } \\
\text { and headache } \\
(57.0 \%) \\
\text { One instance of } \\
\text { fatal pneumonia } \\
(1.5 \%)^{40}\end{array}$ \\
\hline PF-06826647 & $\begin{array}{l}\text { Pfizer (New York } \\
\text { City, New York, } \\
\text { USA) }\end{array}$ & $\begin{array}{l}\text { Moderate- } \\
\text { to-severe } \\
\text { plaque } \\
\text { psoriasis }\end{array}$ & Phase II & Oral & TYK2 inhibitor & $\begin{array}{l}\text { No data } \\
\text { available }\end{array}$ & $\begin{array}{l}\text { No serious, } \\
\text { severe, or fatal } \\
\text { AEs } \\
\text { Patients } \\
\text { experienced } \\
\text { AEs at a rate of } \\
45.5-80.0 \% \text {. All } \\
\text { were mild } \\
\text { Exact nature } \\
\text { of AEs was not } \\
\text { specified. }{ }^{35}\end{array}$ \\
\hline $\begin{array}{l}\text { BMS-986165 } \\
\text { (deucravacitinib) }\end{array}$ & $\begin{array}{l}\text { Bristol Myers } \\
\text { Squibb } \\
\text { (Uxbridge, UK) }\end{array}$ & $\begin{array}{l}\text { Moderate- } \\
\text { to-severe } \\
\text { plaque } \\
\text { psoriasis }\end{array}$ & Phase II & Oral & TYK2 inhibitor & $\begin{array}{l}\text { PASI75 } \\
53.6-58.7 \% \\
\text { (16 weeks), } \\
59.3- \\
69.0 \% \text { (24 } \\
\text { weeks) } 37,40\end{array}$ & $\begin{array}{l}\text { No } \\
\text { opportunistic } \\
\text { infections or } \\
\text { thrombotic } \\
\text { events } \\
\text { Most common } \\
\text { complaints were } \\
\text { nasopharyngitis } \\
\text { (5.7-17.9\%) } \\
\text { and sinusitis } \\
(0-7.6 \%)^{37,40}\end{array}$ \\
\hline BI 730357 & $\begin{array}{l}\text { Boehringer } \\
\text { Ingelheim } \\
\text { (Ingelheim am } \\
\text { Rhein, Germany) }\end{array}$ & $\begin{array}{l}\text { Moderate- } \\
\text { to-severe } \\
\text { plaque } \\
\text { psoriasis }\end{array}$ & Phase II & Oral & $\begin{array}{l}\text { Pyrazinone } \\
\text { RORY } \\
\text { antagonist }\end{array}$ & $\begin{array}{l}\text { No data } \\
\text { available }\end{array}$ & $\begin{array}{l}\text { No data } \\
\text { available }\end{array}$ \\
\hline EDP1815 & $\begin{array}{l}\text { Evelo } \\
\text { Biosciences } \\
\text { (Cambridge, } \\
\text { Massachusetts, } \\
\text { USA) }\end{array}$ & $\begin{array}{l}\text { Mild-to- } \\
\text { moderate } \\
\text { plaque } \\
\text { psoriasis }\end{array}$ & Phase II & Oral & $\begin{array}{l}\text { Monoclonal } \\
\text { strain of } \\
\text { Prevotella } \\
\text { histicola }\end{array}$ & $\begin{array}{l}\text { EASI } 62 \% \\
\text { treatment } \\
\text { difference } \\
\text { versus } \\
\text { placebo }^{54}\end{array}$ & $\begin{array}{l}\text { No difference } \\
\text { in incidence } \\
\text { of diarrhoea, } \\
\text { abdominal } \\
\text { pain, nausea, or } \\
\text { vomiting versus } \\
\text { placebo } \\
\text { No related } \\
\text { serious adverse } \\
\text { events }^{54}\end{array}$ \\
\hline $\begin{array}{l}\text { Medium THC/ } \\
\text { CBD }\end{array}$ & $\begin{array}{l}\text { Brown University } \\
\text { (Providence, } \\
\text { Rhode Island, } \\
\text { USA) }\end{array}$ & $\begin{array}{l}\text { Psoriatic } \\
\text { arthritis }\end{array}$ & Phase II & Oral & $\begin{array}{l}\text { Cannabinoid } \\
\text { receptor } \\
\text { agonist or } \\
\text { via anti- } \\
\text { inflammatory } \\
\text { cholinergic } \\
\text { pathway }\end{array}$ & $\begin{array}{l}\text { No data } \\
\text { available }\end{array}$ & $\begin{array}{l}\text { No data } \\
\text { available }\end{array}$ \\
\hline
\end{tabular}


Table 2 continued.

\begin{tabular}{|c|c|c|c|c|c|c|c|}
\hline Compound & Company & Indications & $\begin{array}{l}\text { Development } \\
\text { state }\end{array}$ & $\begin{array}{l}\text { Route of } \\
\text { administration }\end{array}$ & $\begin{array}{l}\text { Mechanism of } \\
\text { action }\end{array}$ & Efficacy & Adverse effects \\
\hline Naltrexone & $\begin{array}{l}\text { JPMC (Karachi, } \\
\text { Pakistan) }\end{array}$ & $\begin{array}{l}\text { Mild } \\
\text { psoriasis }\end{array}$ & Phase I & Oral & $\begin{array}{l}\mu \text {-opioid } \\
\text { antagonists }\end{array}$ & $\begin{array}{l}\text { PASI score } \\
\text { difference } \\
\text { of } 4.96 \\
\text { comparing } \\
\text { same } \\
\text { patient } \\
\text { cohort } \\
\text { before } \\
\text { and after } \\
\text { treatment } \\
\text { at } 12 \\
\text { weeks }\end{array}$ & $\begin{array}{l}\text { Mood and liver } \\
\text { abnormalities } \\
\text { (requiring } \\
\text { monitoring) } \\
\text { have been } \\
\text { observed at } \\
\text { higher doses }{ }^{46,47}\end{array}$ \\
\hline CC-92252 & $\begin{array}{l}\text { Celgene } \\
\text { (Uxbridge, UK) }\end{array}$ & Psoriasis & Phase I & Oral & $\begin{array}{l}\text { IL-2 receptor } \\
\text { agonist and } \\
\text { regulatory } \\
\text { T-lymphocyte } \\
\text { stimulant }\end{array}$ & $\begin{array}{l}\text { No data } \\
\text { available }\end{array}$ & $\begin{array}{l}\text { No data } \\
\text { available }\end{array}$ \\
\hline
\end{tabular}

ACR2O: American College of Rheumatology score with 20\% improvement; ACR50: American College of Rheumatology score with 50\% improvement; CBD: cannabidiol; EASI: Eczema Area and Severity Index; PASI75: Psoriasis Area and Severity Index with 75\% improvement from baseline; PASI100: Psoriasis Area and Severity Index with 100\% improvement from baseline; PD-1: programmed cell death-1; RORY: retinoic acid receptor-related orphan receptor Y; THC: tetrahydrocannabinol; TYK2: tyrosine kinase 2. 
Table 3: Clinical trial summaries and associated efficacy results.

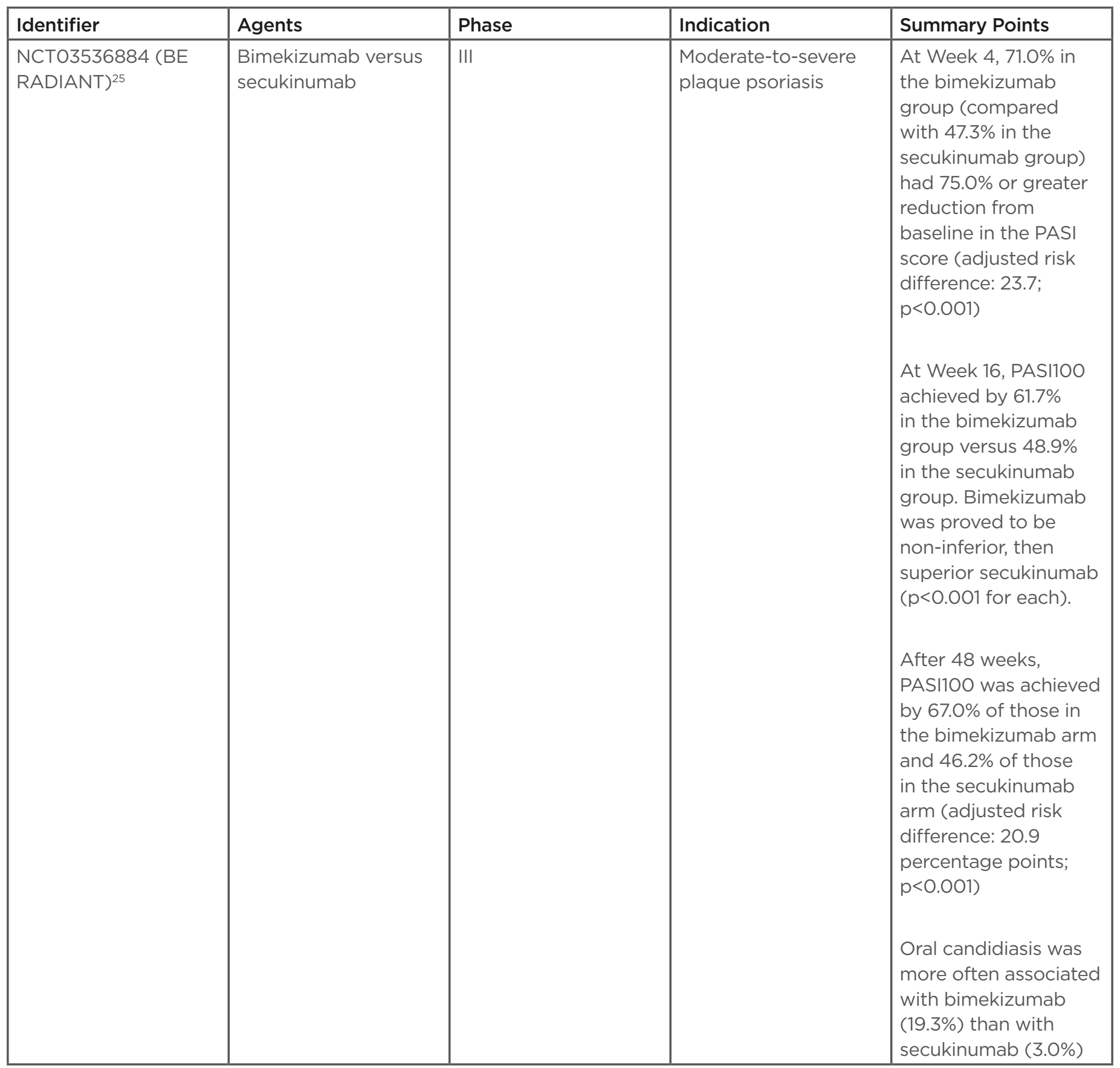


Table 3: Clinical trial summaries and associated efficacy results.

\begin{tabular}{|c|c|c|c|c|}
\hline Identifier & Agents & Phase & Indication & Summary Points \\
\hline $\begin{array}{l}\text { NCTO3101670 } \\
\text { (EQUATOR) }^{82}\end{array}$ & $\begin{array}{l}\text { Filgotinib } \\
\text { (GLPG0634) }\end{array}$ & II & $\begin{array}{l}\text { Moderate-to-severely } \\
\text { active psoriatic } \\
\text { arthritis }\end{array}$ & $\begin{array}{l}\text { At } 16 \text { weeks, } 80.0 \% \\
\text { (52/65) patients in } \\
\text { the filgotinib group } \\
\text { achieved ACR20 } \\
\text { compared with } 33.0 \% \\
(22 / 66) \text { in the placebo } \\
\text { group (p<0.0001) } \\
\text { During the open label } \\
\text { extension portion of } \\
\text { the study, following } \\
52 \text { weeks, 33.6\% of } \\
\text { patients achieved } \\
\text { MDA response and } \\
55.0 \% \text { achieved } \\
\text { ACR50 }\end{array}$ \\
\hline $\begin{array}{l}\text { NCTO3624127 } \\
(\text { POETYK PSO-1) }\end{array}$ & $\begin{array}{l}\text { Deucravacitinib versus } \\
\text { apremilast }\end{array}$ & II & $\begin{array}{l}\text { Moderate-to-severe } \\
\text { plaque psoriasis }\end{array}$ & $\begin{array}{l}\text { Following } 16 \text { weeks } \\
\text { of treatment, PASI75 } \\
\text { was achieved in } 58.7 \% \\
\text { of the deucravactinib } \\
\text { arm, } 35.1 \% \text { of the } \\
\text { apremilast group, and } \\
12.7 \% \text { of the placebo } \\
\text { group } \\
\text { Following } 24 \text { weeks } \\
\text { of treatment, PASI75 } \\
\text { was achieve in } 69.0 \% \\
\text { of the deucravactinib } \\
\text { arm compared } \\
\text { with } 38.1 \% \text { of the } \\
\text { apremilast arm } \\
\text { Of the patients } \\
\text { achieving PASI75 at } \\
24 \text { weeks, } 82.5 \% \text { of } \\
\text { these maintained } \\
\text { PASI75 response at } 52 \\
\text { weeks }\end{array}$ \\
\hline
\end{tabular}


Table 3 contined.

\begin{tabular}{|c|c|c|c|c|}
\hline Identifier & Agents & Phase & Indication & Summary Points \\
\hline $\begin{array}{l}\text { NCTO3611751 } \\
(\text { POETYK PSO-2) })^{39}\end{array}$ & $\begin{array}{l}\text { Deucravacitinib } \\
\text { versus } \\
\text { apremilast } \\
\text { versus } \\
\text { placebo }\end{array}$ & II & $\begin{array}{l}\text { Moderate-to-severe } \\
\text { plaque psoriasis }\end{array}$ & $\begin{array}{l}\text { Following } 16 \text { weeks } \\
\text { of treatment, PASI75 } \\
\text { was achieved in } 53.6 \% \\
\text { of the deucravactinib } \\
\text { arm, } 40.2 \% \text { of the } \\
\text { apremilast arm, and } \\
9.4 \% \text { of the placebo } \\
\text { group } \\
\text { Following } 24 \text { weeks } \\
\text { of treatment, PASI75 } \\
\text { was achieve in } 59.3 \% \\
\text { of the deucravactinib } \\
\text { arm compared } \\
\text { with } 37.8 \% \text { of the } \\
\text { apremilast arm } \\
\text { Of the patients } \\
\text { achieving PASI } 75 \text { at } \\
24 \text { weeks, } 81.4 \% \text { of } \\
\text { these maintained } \\
\text { PASI } 75 \text { response at } 52 \\
\text { weeks }\end{array}$ \\
\hline NCTO373335352 & $\begin{array}{l}\text { EDP1815 versus } \\
\text { placebo }\end{array}$ & I & $\begin{array}{l}\text { Atopic dermatitis, and } \\
\text { patients with mild-to- } \\
\text { moderate psoriasis }\end{array}$ & $\begin{array}{l}\text { Following 56-day } \\
\text { treatment regimen, } \\
\text { there was a } 62 \% \\
\text { difference in EASI } \\
\text { score in EDP1815 } \\
\text { versus placebo } \\
\text { ( } \mathrm{p}=0.034 \text { ) and } 71 \% \\
\text { treatment difference } \\
\text { in IGA*BSA ( } \mathrm{p}=0.019 \text { ) } \\
\text { On Day 56, 10/16 } \\
\text { patients showed } \\
\text { improvements in EASI } \\
\text { (with 3/10 achieving } \\
\text { an EASI75 clinical } \\
\text { response) } \\
\text { In the psoriasis } \\
\text { cohorts, EDP1815 } \\
\text { limited the production } \\
\text { of mediator } \\
\text { inflammatory } \\
\text { cytokines including } \\
\text { 1L-6, IL-8, TNF, and IL-1 }\end{array}$ \\
\hline
\end{tabular}


Table 3 contined.

\begin{tabular}{|c|c|c|c|c|}
\hline Identifier & Agents & Phase & Indication & Summary Points \\
\hline NCTO4250792 & $\begin{array}{l}\text { Naltrexone post- } \\
\text { versus pre-treatment }\end{array}$ & I & Mild psoriasis & $\begin{array}{l}\text { Following } 12 \text { weeks of } \\
\text { low dose naltrexone } \\
\text { therapy, PASI score } \\
\text { difference of } 4.96 \\
\text { ( } p<0.001 \text { ), DLQI } \\
\text { score difference of } \\
6.32 \text { ( } p<0.001 \text { ),and } \\
\text { a IGA*BSA score } \\
\text { difference of } 3.9 \\
\text { ( } p<0.001 \text { ) compared } \\
\text { with observations } \\
\text { of the same group } \\
\text { before treatment }\end{array}$ \\
\hline
\end{tabular}

ACR20: American College of Rheumatology score with 20\% improvement; ACR50: American College of Rheumatology score with 50\% improvement; DLQI: Dermatology Life Quality Index; EASI: Eczema Area and Severity Index; IGA*BSA: Investigator's Global Assessment and Body Surface Area; MDA: minimal disease activity; PASI75: Psoriasis Area and Severity Index with 75\% improvement from baseline; PASI100: Psoriasis Area and Severity Index with $100 \%$ improvement from baseline.

\section{References}

1. Afonina IS et al. Immune responses and therapeutic options in psoriasis. Cell Mol Life Sci. 2021;78(6):2709-27.

2. Rendon A, Schäkel K. Psoriasis pathogenesis and treatment. Int $\mathrm{J} \mathrm{Mol}$ Sci. 2019;20(6):1475.

3. Balogh EA et al. Emerging systemic drugs in the treatment of plaque psoriasis. Expert Opin Emerg Drugs. 2020;25(2):89-100

4. Bagel J, Gold LS. Combining topical psoriasis treatment to enhance systemic and phototherapy: a review of the literature. J Drugs Dermatol. 2017;16(12):1209-22.

5. Armstrong AW, Read C. Pathophysiology, clinical presentation, and treatment of psoriasis: a review. JAMA.
2020;323(19):1945-60.

6. Foerster J, Dawe R. Phototherapy achieves significant cost savings by the delay of drug-based treatment in psoriasis. Photodermatol Photoimmunol Photomed. 2020;36(2):90-6.

7. Housman TS et al. Phototherapy utilization for psoriasis is declining in the United States. J Am Acad Dermatol. 2002;46(4):557-9.

8. Ighani A et al. Comparison of management guidelines for moderate-to-severe plaque psoriasis: a review of phototherapy, systemic therapies, and biologic agents. J Cutan Med Surg. 2019;23(2):204-21.

9. Menter A et al. Adalimumab therapy for moderate to severe psoriasis: a randomized, controlled Phase III trial. J Am Acad Dermatol. 2008;58(1):10615.

10. Menter A et al. A randomized comparison of continuous vs. intermittent infliximab maintenance regimens over 1 year in the treatment of moderate-to-severe plaque psoriasis. J Am Acad Dermatol. 2007;56(1):31.e1-15.

11. Langley RG et al. Long-term efficacy and safety of ustekinumab, with and without dosing adjustment, in patients with moderate-to-severe psoriasis: results from the PHOENIX 2 study through 5 years of follow-up. $\mathrm{Br}$ J Dermatol. 2015;172(5):1371-83.

12. Papp KA et al. Etanercept Psoriasis Study Group. A global Phase III 
randomized controlled trial of etanercept in psoriasis: safety, efficacy, and effect of dose reduction. Br J Dermatol. 2005;152(6):1304-12.

13. Kircik L et al.; Unite Study Group. Utilization of narrow-band ultraviolet light B therapy and etanercept for the treatment of psoriasis (UNITE): efficacy, safety, and patient-reported outcomes. J Drugs Dermatol. 2008;7(3):245-53.

14. Menter A et al. Drug survival of biologic therapy in a large, diseasebased registry of patients with psoriasis: results from the Psoriasis Longitudinal Assessment and Registry (PSOLAR). J Eur Acad Dermatol Venereol. 2016;30(7):114858.

15. Gaspari AA, Tyring S. New and emerging biologic therapies for moderate-to-severe plaque psoriasis: mechanistic rationales and recent clinical data for IL-17 and IL-23 inhibitors. Dermatol Ther. 2015:28(4):179-93.

16. U.S. Food and Drug Administration (FDA). Biosimilar product information. Available at: https:// www.fda.gov/drugs/biosimilars/ biosimilar-product-information. Last Accessed: 7 May 2021

17. Sandoz. Study to demonstrate equivalent efficacy and to compare safety of biosimilar adalimumab (GP2017) and humira. NCTO2016105. https://ClinicalTrials.gov/show/ NCT02016105.

18. Global News Wire. Adalimumab biosimilar landscape report provides an analysis. 2021. Available at: https:// www.globenewswire.com/newsrelease/2021/01/20/2161094/0/en/ Adalimumab-Biosimilar-LandscapeReport-Provides-an-Analysis-of-35Companies-along-with-Updated45-Marketed-and-Pipeline-DrugsDelvelnsight.html. Last accessed: 12 October 2021.

19. Coherus BioSciences Inc. Coherus BLA filing for adalimumab biosimilar candidate accepted by FDA for review. 2021. Available at: https:// investors.coherus.com/news-releases/ news-release-details/coherusbla-filing-adalimumab-biosimilarcandidate-accepted-fda. Last accesssed: 7 May 2021.

20. Bilal $\mathrm{J}$ et al. A systematic review and meta-analysis of the efficacy and safety of the interleukin (IL)-12/23 and IL-17 inhibitors ustekinumab, secukinumab, ixekizumab, brodalumab, guselkumab and tildrakizumab for the treatment of moderate to severe plaque psoriasis. J Dermatolog Treat. 2018;29(6):569 78.

21. Armstrong AW et al. Comparative efficacy and relative ranking of biologics and oral therapies for moderate-to-severe plaque psoriasis: a network meta-analysis. Dermatol
Ther (Heidelb). 2021;11(3):885-905.

22. Kim WB et al. Diagnosis and management of psoriasis. Can Fam Physician. 2017;63(4):278-85.

23. Cheng J, Feldman SR. The cost of biologics for psoriasis is increasing. Drugs Context. 2014;3:212266.

24. Fleming WK. Pharmacy management strategies for improving drug adherence. J Manag Care Pharm. 2008;14(6 Suppl B):16-20.

25. UCB Biopharma SR. A study to evaluate the safety and efficacy of bimekuzinab compared to an active comparator in adult subjects with moderate-to-severe chronic plaque psoriasis (BE RADIANT). NCT03536884. https://clinicaltrials. gov/ct2/show/NCT03536884.

26. Reich $\mathrm{K}$ et al. Bimekizumab versus secukinumab in plaque psoriasis. $\mathrm{N}$ Engl J Med. 2021;385(2):142-52.

27. Gordon KB et al. Bimekizumab efficacy and safety in moderate to severe plaque psoriasis (BE READY): a multicentre, double-blind, placebo-controlled, randomised withdrawal Phase 3 trial. Lancet. 2021;397(10273):475-86.

28. Papp KA et al. Dual neutralization of both interleukin 17A and interleukin $17 \mathrm{~F}$ with bimekizumab in patients with psoriasis: results from $B E A B L E$ 1, a 12-week randomized, doubleblinded, placebo-controlled Phase $2 \mathrm{~b}$ trial. J Am Acad Dermatol. 2018;79(2):277-86.e10

29. Colgene. Study to evaluate the safety, tolerability, pharmacokinetics, pharmacodynamics, and immunogenicity of CC-90006 in subjects with mild to moderate plaque-type psoriasis. NCT03337022 https://ClinicalTrials.gov/show/ NCT03337022.

30. Grebinoski S, Vignali DA. Inhibitory receptor agonists: the future of autoimmune disease therapeutics? Curr Opin Immunol. 2020;67:1-9.

31. Galapagos. Filgotinib. 2021. Available at: https://www.glpg.com/filgotinib. Last accessed: 14 June 2021.

32. Mease $P$ et al. Efficacy and safety of filgotinib, a selective Janus kinase 1 inhibitor, in patients with active psoriatic arthritis (EQUATOR): results from a randomised, placebocontrolled, Phase 2 trial. Lancet. 2018:392(10162):2367-77.

33. Gladman DD et al. FRIO339 Longterm efficacy of the oral selective janus kinase 1 inhibitor filgotinib in psoriatic arthritis: week 52 response patterns in individual patients from an open-label extension (OLE) study (EQUATOR2). Ann Rheum Dis. 2020;79:763

34. Gilead. New analyses of phase 2 EQUATOR clinical program support durable efficacy of filgotinib in psoriatic arthritis. 2020. Available at: https://www.gilead.com/ news-and-press/press-room/ press-releases/2020/6/newanalyses-of-phase-2-equator-clinicalprogram-support-durable-efficacyof-filgotinib-in-psoriatic-arthritis. Last Accessed: 19 May 2020

35. Pfizer. A study to evaluate safety and efficacy of PF-06826647 for moderate to severe plaque psoriasis. NCT03895372. https://ClinicalTrials. gov/show/NCT03895372

36. Pfizer. A first in human study to evaluate safety, tolerability, and pharmacology of PF-06826647 in healthy subjects and subjects with plaque psoriasis. NCT03210961. https://clinicaltrials.gov/ct2/show/ NCT03210961.

37. Business Wire. Bristol Myers Squibb presents positive data from two pivotal phase 3 psoriasis studies demonstrating superiority of deucravacitinib compared to placebo and Otezla ${ }^{\circledR}$ (apremilast). 2021. Available at: https:// www.businesswire.com/news/ home/20210423005134/en/BristolMyers-Squibb-Presents-PositiveData-from-Two-Pivotal-Phase-3Psoriasis-Studies-DemonstratingSuperiority-of-DeucravacitinibCompared-to-Placebo-andOtezla\%C2\%AE-apremilast. Last accessed: 14 June 2021.

38. Bristol-Myers Squibb. Effectiveness and safety of BMS-986165 compared to placebo and active comparator in participants with psoriasis (POETYK-PSO-1). NCT03624127. https://clinicaltrials.gov/ct2/show/ NCT03624127.

39. Bristol-Myers Squibb. An investigational study to evaluate experimental medication BMS986165 compared to placebo and currently available treatment in participants with moderate-to-severe plaque psoriasis (POETYK-PSO-2) NCT03611751. https://clinicaltrials.gov/ ct2/show/NCT03611751.

40. Mease PJ et al. Efficacy and safety of deucravacitinib (BMS-986165) an oral, selective tyrosine kinase 2 inhibitor, in patients with active psoriatic arthritis: results from a Phase 2, randomized, double-blind, placebo-controlled trial. Abstract LO3. ACR Convergence 2020, 5-9 November, 2020

41. Zhang $Y$ et al. ROR nuclear receptors: structures, related diseases, and drug discovery. Acta Pharmacol Sin. 2015;36(1):71-87.

42. Boehringer Ingelheim. A study to test how well patients with plaque psoriasis tolerate BI 730357 over a longer period and how effective it is NCT03835481. https://ClinicalTrials. gov/show/NCT03835481.

43. Boehringer Ingelheim. This study is done in patients with plaque psoriasis and tests how well they tolerate 
BI 730357 and how effective it is. NCT03635099. https://ClinicalTrials. gov/show/NCT03635099.

44. Celgene. A safety study of CC-92252 in healthy adult subjects and adult subjects with psoriasis. NCTO3971825. https://ClinicalTrials.gov/show/ NCT03971825.

45. Jinnah Postgraduate Medical Centre (JPMC). Efficacy of low dose naltrexone in psoriasis. NCT04250792. https://clinicaltrials. gov/ct2/show/NCTO4250792.

46. Weinstock LB et al. Low-dose naltrexone therapy for psoriasis. Int J Pharm Compd. 2020;24(2):94-6.

47. Lee B, Elston DM. The uses of naltrexone in dermatologic conditions. J Am Acad Dermatol. 2019;80(6):1746-52.

48. Milando R, Friedman A. Cannabinoids: potential role in inflammatory and neoplastic skin diseases. Am J Clin Dermatol. 2019;20(2):167-80.

49. Brown University. Impact of cannabis on pain and inflammation among patients with rheumatoid or psoriatic arthritis. NCTO4269993. https://ClinicalTrials.gov/show/ NCT04269993.

50. Derakhshan N, Kazemi M. Cannabis for refractory psoriasis-high hopes for a novel treatment and a literature review. Curr Clin Pharmacol. 2016;11(2):146-7.

51. Itano AC et al. 16003 Orally administered EDP1815, a monoclonal strain of Prevotella histicola, has potent systemic anti-inflammatory effects. JAAD. 2020;83(6):AB52.

52. Evelo Biosciences, Inc. A Phase 2 study investigating the effect of EDP1815 in the treatment of mild to moderate plaque psoriasis. NCT04603027. https://ClinicalTrials. gov/show/NCT04603027.

53. Evelo Biosciences Inc. A study of EDP1815 in healthy participants and participants with mild-to-moderate psoriasis and atopic dermatitis. NCT03733353. https://clinicaltrials. gov/ct2/show/NCTO3733353.

54. Global News Wire. Evelo Biosciences reports positive topline clinical data in phase 1b trial of EDP1815 in atopic dermatitis. 2020. Available at: https:// www.globenewswire.com/newsrelease/2020/12/09/2142090/0/en/ Evelo-Biosciences-Reports-PositiveTopline-Clinical-Data-in-Phase-1bTrial-of-EDP1815-in-Atopic-Dermatitis. html. Last Accessed: 7 May 2021.

55. Balkwill F. Tumour necrosis factor and cancer. Nat Rev Cancer. 2009;9(5):361-71.

56. Dogra S, Khullar G. Tumor necrosis factor-alpha antagonists: side effects and their management. Indian $\mathrm{J}$ Dermatol Venereol Leprol. 2013;79 Suppl 7:S35-46.
57. Blauvelt A et al. Efficacy and safety of guselkumab, an anti-interleukin-23 monoclonal antibody, compared with adalimumab for the continuous treatment of patients with moderate to severe psoriasis: results from the Phase III, double-blinded, placeboand active comparator-controlled VOYAGE 1 trial. J Am Acad Dermatol. 2017;76(3):405-17.

58. Ghazawi FM et al. A review of the efficacy and safety for biologic agents targeting IL-23 in treating psoriasis with the focus on tildrakizumab. Front Med (Lausanne). 2021:8:702776.

59. Gordon KB et al. Efficacy and safety of risankizumab in moderate-tosevere plaque psoriasis (UItIMMa-1 and UItIMMa-2): results from two double-blind, randomised, placebocontrolled and ustekinumabcontrolled Phase 3 trials. Lancet. 2018:392(10148):650-61.

60. Loft ND et al. Adverse events with IL-17 and IL-23 inhibitors for psoriasis and psoriatic arthritis: a systematic review and meta-analysis of Phase III studies. J Eur Acad Dermatol Venereol. 2020;34(6):1151-60.

61. Sbidian E et al. Systemic pharmacological treatments for chronic plaque psoriasis: a network meta-analysis. Cochrane Database Syst Rev. 2020;1(1):CD011535.

62. Bolick NL et al. Management of plaque psoriasis: a review and comparison of IL-23 ilnhibitors. EMJ Dermatol. 2020;8(1):84-95.

63. Wasilewska A et al. Interleukin-17 inhibitors. A new era in treatment of psoriasis and other skin diseases. Postepy Dermatol Alergol. 2016;33(4):247-52

64. Langley RG et al. Secukinumab in plaque psoriasis - results of two Phase 3 trials. N Engl J Med. 2014;371(4):326-38

65. Papp KA et al. Brodalumab an anti-interleukin-17-receptor antibody for psoriasis. N Engl J Med. 2012;366(13):1181-9.

66. Warren RB et al. Bimekizumab versus adalimumab in plaque psoriasis. $\mathrm{N}$ Engl J Med. 2020;385(2):130-41.

67. Jadon DR et al. Applying precision medicine to unmet clinical needs in psoriatic disease. Nat Rev Rheumatol. 2020;16(11):609-27.

68. Grajdeanu IA et al. Imaging techniques in the diagnosis and monitoring of psoriasis. Exp Ther Med. 2019;18(6):4974-80.

69. Duan $X$ et al. Inhibition of keratinocyte necroptosis mediated by RIPK1/RIPK3/MLKL provides a protective effect against psoriatic inflammation. Cell Death Dis. 2020;11(2):134.

70. Wu $Q$ et al. Pentraxin 3: a promising therapeutic target for autoimmune diseases. Autoimmun Rev. 2020;19(12):102584.

71. Xiuli Y, Honglin W. miRNAs flowing up and down: the concerto of psoriasis. Front Med (Lausanne). 2021;8:646796.

72. Sun S et al. Circulating CD14+HLA DR-/low myeloid-derived suppressor cells as potential biomarkers for the identification of psoriasis TCM bloodheat syndrome and blood-stasis syndrome. Evid Based Complement Alternat Med. 2020;2020:4582459.

73. Carroll CL et al. Better medication adherence results in greater improvement in severity of psoriasis. $\mathrm{Br}$ J Dermatol. 2004;151(4):895-7.

74. Feldman SR et al. Patterns of medication utilization and costs associated with the use of etanercept, adalimumab, and ustekinumab in the management of moderate-to-severe psoriasis. J Manag Care Spec Pharm. 2015;21(3):201-9.

75. Cao Z et al. Ustekinumab dosing, persistence, and discontinuation patterns in patients with moderateto-severe psoriasis. J Dermatolog Treat. 2015;26(2):113-20.

76. Baiano R et al. Psoriasis patients utilizing secukinumab, ixekizumab, or brodalumab - comparisons to prior biologic medication adherence levels, reasons for switching, and reported changes in disease symptoms. Journal of Drug Assessment. 2019;8(Suppl 1):3.

77. Hambly R et al. Medication adherence among patients with psoriasis on traditional systemic and biologics treatment. $\mathrm{Br} \mathrm{J}$ Dermatol. 2018;178(1):e46-8.

78. Vangeli E et al. A systematic review of factors associated with nonadherence to treatment for immunemediated inflammatory diseases. Adv Ther. 2015;32(11):983-1028.

79. Murage MJ et al. Medication adherence and persistence in patients with rheumatoid arthritis, psoriasis, and psoriatic arthritis: a systematic literature review. Patient Prefer Adherence. 2018;12:1483-503.

80. Svendsen MT et al. eHealth technologies as an intervention to improve adherence to topical antipsoriatics: a systematic review. J Dermatolog Treat. 2018;29(2):123-8.

81. Wang $W$ et al. Poor medication adherence in patients with psoriasis and a successful intervention. $J$ Dermatolog Treat. 2019;30(6):525-8

82. Galapagos NV. A study to assess efficacy and safety of filgotinib in active psoriatic arthritis (EQUATOR). NCT03101670. https://clinicaltrials. gov/ct2/show/NCT03101670. 